\title{
FACTORS ASSOCIATED TO INFECTION BY TOXoplasma gondii IN PREGNANT WOMEN ATTENDED IN BASIC HEALTH UNITS IN THE CITY OF ROLÂNDIA, PARANÁ, BRAZIL
}

Renata Cristina Ferreira DIAS(1), Fabiana Maria Ruiz LOPES-MORI(2), Regina MITSUKA-BREGANÓ(2), Rafael André Ferreira DIAS(3), Deise Vieira TOKANO(3), Edna Maria Vissoci REICHE(4), Roberta Lemos FREIRE(5) \& Italmar Teodorico NAVARRO(5)

\begin{abstract}
SUMMARY
The aim of the present work was to determine the prevalence of $\operatorname{IgG}$ and IgM anti-Toxoplasma gondii antibodies and the factors associated to the infection in pregnant women attended in Basic Health Units in Rolândia, Paraná, Brazil. The sample was divided in two groups: group I (320 pregnant women who were analyzed from July 2007 to February 2008) and group II (287 pregnant women who were analyzed from March to October 2008). In group I, it was found 53.1\% of pregnant women with IgG reactive and IgM nonreactive, $1.9 \%$ with $\operatorname{IgG}$ and $\operatorname{IgM}$ reactive, $0.3 \%$ with $\operatorname{IgG}$ non-reactive and $\operatorname{IgM}$ reactive and $44.7 \%$ with $\operatorname{IgG}$ and $\operatorname{IgM}$ non-reactive. In group II, it was found $55.1 \%$ with $\mathrm{IgG}$ reactive and $\operatorname{IgM}$ non-reactive and $44.9 \%$ with $\operatorname{IgG}$ and $\operatorname{IgM}$ non-reactive. The variables associated to the presence of IgG antibodies were: residence in rural areas, pregnant women between 35-40 years old, low educational level, low family income, more than one pregnancy, drinking water which does not originate from the public water supply system and the habit of handling soil or sand. Guidance on primary prevention measures and the quarterly serological monitoring of the pregnant women in the risk group are important measures to prevent congenital toxoplasmosis.
\end{abstract}

KEYWORDS: Toxoplasmosis; Risk factors; Diagnostic; Congenital disease.

\section{INTRODUCTION}

Toxoplasmosis is a worldwide infection caused by Toxoplasma gondii $^{46}$, an obligatory intracellular parasite that infects warm-blooded animals, including human beings ${ }^{30}$. It is believed that up to one third of the world's population is infected ${ }^{21}$. The prevalence of infection by $T$. gondii in humans varies among different countries, geographical regions within a country, social and economic strata and cultural habits ${ }^{57}$.

Countries with a high level of toxoplasmosis have instituted and obtained success in secondary prevention programs by screening maternal serum $^{26}$. In the acute infection, the levels of immunoglobulin $\mathrm{G}(\mathrm{IgG})$ and immunoglobulin $\mathrm{M}(\operatorname{IgM})$ increase between one and two weeks of infection ${ }^{44}$. Positive IgM results should be confirmed in a reference laboratory ${ }^{60}$ with capability to delimit the infection period by using specific tests such as the $\mathrm{IgG}$ avidity test ${ }^{31}$.

For occurrence of congenital toxoplasmosis, the primary infection should be established during pregnancy ${ }^{16}$. Among women infected by $T$. gondii during pregnancy, $61 \%$ do not transmit the disease to the fetus, $26 \%$ of the conceptions present subclinical infection (visual/or hearing deficit, neuromotor and/or learning deficit) and in $13 \%$ there is a clinical infection (hydrocephalus or microcephaly, chorioretinitis, cerebral calcification and mental retardation $)^{43}$.
The importance of implanting maternal serum screening to detect toxoplasmosis lies in the possibility of adopting prophylactic and therapeutic measures to minimize the vertical transmission and/or decrease the damage to fetus development ${ }^{15}$. In the face of the seriousness of the congenital disease, it is fundamental to start prenatal care in the first three months of pregnancy, so that, acute cases of congenital toxoplasmosis can be early identified ${ }^{40}$.

The aim of the present study was to assess the factors associated to infection by $T$. gondii and determine the prevalence of $\operatorname{IgG}$ and $\operatorname{IgM}$ anti-T. gondii antibodies in pregnant women attended in Basic Health Units (BHU) of Rolândia, Paraná, during the implementation of the "Surveillance Program of Toxoplasmosis Acquired in Pregnancy and Congenital".

\section{MATERIAL AND METHODS}

A cross-sectional study was carried out in pregnant women who received prenatal care in the six BHU in the city of Rolândia, Paraná, with an average of 750 per year attended by the Brazilian Public Health Service. The city is located in the north of Paraná State, the metropolitan region of Londrina, and has a population of 56,352 inhabitants ${ }^{52}$.

In the study, all the pregnant women who entered for the first prenatal visit in the BHU were evaluated and filled out a term of free and informed

(1) Post-graduate School, Animal Science, Department of Preventive Veterinary Medicine; State University of Londrina (UEL); Londrina, Paraná, Brazil.

(2) Professor of Department of Pathological Science, UEL; Londrina, Paraná, Brazil.

(3) Municipal Health Secretariat of Rolândia; Rolândia, Paraná, Brazil.

(4) Professor of Department of Pathology, Clinical Analysis and Toxicology, Health, UEL; Londrina, Paraná, Brazil.

(5) Professor of Department of Preventive Veterinary Medicine, UEL; Londrina, Paraná, Brazil.


990 Londrina, Paraná, Brasil. Phone/Fax: (43) 3371 4485. E-mail: italmar@uel.br 


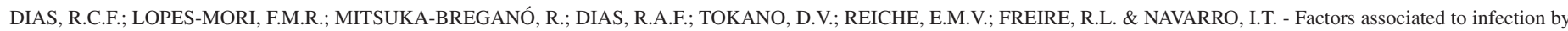
Toxoplasma gondii in pregnant women attended in Basic Health Units in the city of Rolândia, Paraná, Brazil. Rev. Inst. Med. Trop. Sao Paulo, 53(4): 185-91, 2011.

consent and an epidemiological questionnaire. The prenatal screening program was set up in July 2007. Before the program implementation, the serological test for toxoplasmosis was not included in the pre-natal routine. In conjunction with the State University of Londrina and the Municipal Health Secretariat of Rolândia, Paraná, the program actions were established according to the characteristics of the health service of the city.

In March, 2009, the serological exams for toxoplasmosis were carried out by a private laboratory contracted by the Municipal Health Secretariat of Rolândia, Paraná, and was oriented to determine a new serological test based on the "Acquired Toxoplasmosis in Pregnancy and Congenital: Health Surveillance, Diagnosis, Treatment and Conduct" 42 . Thus the Indirect Immunofluorescence Assay (IFA) and the EnzymeLinked Immunosorbent Assay (ELISA) were used to research IgG anti- $T$. gondii antibodies, as they had a good correlation ${ }^{14,58}$.

Based on the change in technique to detect $\operatorname{IgG}$ and $\operatorname{IgM}$ anti-T. gondii antibodies, the pregnant women were divided into two groups and two phases:

Group I (G I) - First phase of the study: In this group, pregnant women were attended from July 2007 to February 2008. The research of IgG anti-T. gondii was performed by Indirect Immunofluorescence Assay (IFA), with a cut off point of $1: 16^{13}$ and the research of $\operatorname{IgM}$ antibodies was performed by Microparticle Enzyme Immunoassay (MEIA) (Abbott Laboratories, Illinois, USA). The serological tests were carried out at the Immunology Laboratory of the University Hospital of Londrina.

Group II (G II) - Second phase of the study: In this group, pregnant women were attended from March to October 2008. The research of IgG anti-T. gondii was performed by the ELISA technique, with a cut off point of $15.0 \mathrm{UI} / \mathrm{mL}$ and the research of IgM antibodies was performed by Capture ELISA, with a cut off point $1.1 \mathrm{UI} / \mathrm{mL}$, both from DiaSorin ${ }^{\circledR}$ (DIASORIN, Saluggia, Italy). The serological tests were carried out in a private contracted laboratory.

The reactive IgG and IgM samples, in both groups, were assessed by the IgG avidity test LIAISON ${ }^{\circledR}$ (DIASORIN, Saluggia, Italy) to detect possible acute infection.
The present study was approved by the Ethics Committee for Research in Human Beings at the State University of Londrina, document number 182/07 and was carried out in conjunction with the Municipal Secretariat of Health of Rolândia, Paraná.

\section{RESULTS}

Table 1 shows the prevalence of $\operatorname{IgG}$ and $\operatorname{IgM}$ in pregnant women in G I and G II, and the general prevalence presented. The analysis of proportions showed that there was no prevalence difference between the groups, that is, the infection rate in both tests were similar (Table 1).

In $\mathrm{G}$ I, all the six sera samples $\mathrm{IgG}$ and IgM reactive were submitted to the $\operatorname{IgG}$ avidity test and they showed strong results. The pregnant women who had non-reactive $\operatorname{IgG}$ but reactive $\operatorname{IgM}$ were submitted to a new serology test 15 days later and the same result was obtained.

Among 176 pregnant women with reactive IgG, 35 (19.9\%) presented titters of $16,73(41.5 \%)$ of $64,49(27.8 \%)$ of $256,17(9.7 \%)$ of 1024 and two $(1.1 \%)$ of 4000 .

Tables 2 and 3 show the factors associated to the presence of IgG anti-T. gondii antibodies which were: residence in rural area $(p=0.0140)$, pregnant women between 35 and 40 years $(p=0.0043)$, low educational level ( $\leq 8$ years of study) ( $p=<0.0001)$, monthly family income less than one minimum wage $(p=0.0220)$, more than one pregnancy $(p=0.0116)$, drinking water which does not originate from the public water supply system $(p=0.0011)$, the habit of handling soil or sand $(p=0.0497)$ and a tendency $(p=0.0524)$ in the habit of handling raw meat.

\section{DISCUSSION}

This was the first epidemiological study carried out with pregnant women in the city of Rolândia, Paraná, Brazil, in which the prevalence of IgG anti-T. gondii antibodies found was $55.0 \%$ and $55.1 \%$ in groups I and II, respectively, and the general prevalence was $55 \%$. The prevalence detected for IgM anti-T. gondii antibodies was $2.2 \%$.

The prevalence of IgG anti-T. gondii antibodies was similar to the

Table 1

Prevalence of IgG and IgM anti-Toxoplasma gondii antibodies in 670 pregnant women attended in Basic Health Units in Rolândia, Paraná, 2007-2008

\begin{tabular}{|c|c|c|c|c|}
\hline \multirow[t]{2}{*}{ Antibodies } & \multicolumn{2}{|c|}{ Prevalence/total (\%) } & \multirow[t]{2}{*}{$p$ value } & \multirow[t]{2}{*}{ General prevalence/total $(\%)$} \\
\hline & Group 1 & Group 2 & & \\
\hline
\end{tabular}

\section{Seropositivity}

$\operatorname{IgG}(+) ; \operatorname{IgM}(-)$

$170 / 320(53.1)$

$158 / 287(55.1)$

$\operatorname{IgG}(+)$

$\operatorname{IgG}(+) ; \operatorname{IgM}(+)$

$6 / 320(1.9)$

0

0.6934

Total

$176 / 320(55.0)$

158/287 (55.1)

$334 / 607$ (55)

\section{Susceptibility}

$\operatorname{IgG}(-) ; \operatorname{IgM}(-)$

$143 / 320(44.7)$

129/287 (44.9)

IgG (-)

$\operatorname{IgG}(-) ; \operatorname{IgM}(+)$

$1 / 320(0.3)$

0

0.9861

Total

$144 / 320(45.0)$

129/287 (44.9)

273/607 (45)

(+) reactive; (-) non-reactive. 


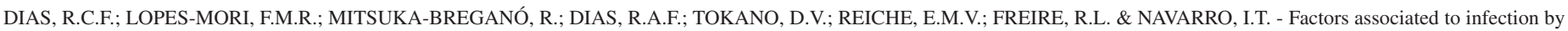
Toxoplasma gondii in pregnant women attended in Basic Health Units in the city of Rolândia, Paraná, Brazil. Rev. Inst. Med. Trop. Sao Paulo, 53(4): 185-91, 2011.

Table 2

Analysis of the socioeconomic variables associated to the presence of $\mathrm{IgG}$ anti-Toxoplasma gondii antibodies in pregnant women attended in Basic Health Units in Rolândia, Paraná, 2007-2008

\begin{tabular}{|c|c|c|c|}
\hline Variables & Reactive IgG/total (\%) & $p$ & Odds ratio (CI 95\%) \\
\hline \multicolumn{4}{|l|}{ Residence } \\
\hline Rural area & 28/37 (75.68) & 0.0140 & $2.70(1.19-6.29)$ \\
\hline Urban area & $305 / 570(53.51)$ & & \\
\hline \multicolumn{4}{|l|}{ Age group (years) } \\
\hline $15-24 *$ & $137 / 276(49.64)$ & & \\
\hline $25-35$ & $151 / 267(56.55)$ & 0.1263 & $1.32(0.93-1.88)$ \\
\hline $36-45$ & 45/64 (70.31) & 0.0043 & $2.40(1.29-4.51)$ \\
\hline \multicolumn{4}{|l|}{ Educational level } \\
\hline$\leq 8$ years of school & $85 / 124(68.55)$ & 0.0008 & $2.07(1.34-3.22)$ \\
\hline$>8$ years of school & $247 / 482(51.24)$ & & \\
\hline \multicolumn{4}{|l|}{ Monthly family income** } \\
\hline less than one M.W.* & $32 / 42(76.19)$ & & \\
\hline From 1 to $3 \mathrm{M} . \mathrm{W}$. & $247 / 436(56.65)$ & 0.0220 & $0.41(0.18-0.89)$ \\
\hline More than 3 M.W. & $52 / 101(51.49)$ & 0.0108 & $0.33(0.14-0.80)$ \\
\hline \multicolumn{4}{|l|}{ Number of pregnancies } \\
\hline One pregnancy & $118 / 267(44.19)$ & 0.0116 & $0.69(0.52-0.92)$ \\
\hline More than one pregnancy & $215 / 338(63.61)$ & & \\
\hline \multicolumn{4}{|c|}{$\begin{array}{l}\text { Drinking water does not originate from the public } \\
\text { water supply system }\end{array}$} \\
\hline Yes & $304 / 571(53.24)$ & 0.0011 & $0.24(0.09-0.61)$ \\
\hline No & $29 / 35(82.86)$ & & \\
\hline
\end{tabular}

*Reference category; ** M.W. = Minimum wage current (R\$380,00 until march 2008, R\$ 415,00 after march 2008).

Table 3

Analysis of the alimentary and hygiene habits and behavior variables associated to the presence of IgG anti-Toxoplasma gondii antibodies in pregnant women attended in Basic Health Units in Rolândia, Paraná, 2007-2008

\begin{tabular}{|c|c|c|c|}
\hline Variables & Reactive IgG/total (\%) & $p$ & Odds ratio (CI 95\%) \\
\hline \multicolumn{4}{|c|}{ Presence of vegetable garden at home } \\
\hline Yes & $60 / 99(60.60)$ & 0.2520 & $1.32(0.83-2.10)$ \\
\hline No & $273 / 508(53.74)$ & & \\
\hline \multicolumn{4}{|c|}{ Contact with cats } \\
\hline Yes & $30 / 63(47.62)$ & 0.2773 & $0.72(0.42-1.26)$ \\
\hline No & $303 / 544(55.70)$ & & \\
\hline \multicolumn{4}{|c|}{ Habit of consumption of raw or poorly cooked meat } \\
\hline Yes & $74 / 128(57.81)$ & 0.6145 & $1.13(0.75-1.71)$ \\
\hline No & $256 / 467(54.82)$ & & \\
\hline \multicolumn{4}{|c|}{ Habit of handling soil or sand } \\
\hline Yes & $43 / 64(67.18)$ & 0.0497 & $1.79(1.00-3.21)$ \\
\hline No & $290 / 543(53.41)$ & & \\
\hline \multicolumn{4}{|c|}{ Habit of eating raw vegetables } \\
\hline Yes & $277 / 491(56.42)$ & 0.1386 & $1.39(0.91-2.12)$ \\
\hline No & $56 / 116(48.27)$ & & \\
\hline \multicolumn{4}{|c|}{ Habit of handling raw meat } \\
\hline Yes & $289 / 510(56.66)$ & 0.0524 & $1.58(1.00-2.49)$ \\
\hline No & $44 / 97(45.36)$ & & \\
\hline
\end{tabular}




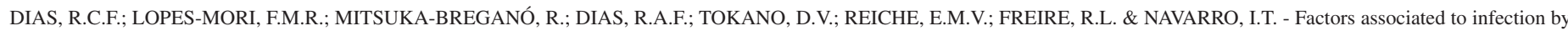
Toxoplasma gondii in pregnant women attended in Basic Health Units in the city of Rolândia, Paraná, Brazil. Rev. Inst. Med. Trop. Sao Paulo, 53(4): $185-91,2011$.

findings in studies carried out in pregnant women in other states of Brazil, such as the $54.8 \%$ prevalence found in Pelotas, Rio Grande do $\mathrm{Sul}^{12}, 57.3 \%$ in São José do Rio Preto, São Paulo ${ }^{27}, 59.8 \%{ }^{59}$ and $61.1 \%{ }^{49}$ both in Porto Alegre, Rio Grande do Sul State. In the city of Londrina, also in the north of the of Paraná State, LOPES et. al. $(2009)^{38}$ and MITSUKA-BREGANÓ $(2009)^{41}$ detected $49.2 \%$ and $50.5 \%$ reactive sera for $\mathrm{IgG}$, respectively. Higher values were reported in other regions, such as: $71.5 \%$ in Fortaleza, Ceará State ${ }^{51}, 73.5 \%$ in Vitória, Espírito Santo State ${ }^{5}$ and $74.5 \%$ in the region of Alto Uruguai, northwest of Rio Grande do $\mathrm{Sul}^{56}$.

The Brazilian data are higher when compared to other countries: $9.1 \%$ in the United Kindgom ${ }^{45}, 10.6 \%$ in China ${ }^{37}, 10.9 \%$ in Norway ${ }^{32}, 28.6 \%$ in Spain ${ }^{9}, 29.4 \%$ in Greece ${ }^{3}$ and $30.1 \%$ in Turkey ${ }^{25}$. The prevalence of seropositive individuals for $T$. gondii varies greatly among the different regions of the world. Several factors can interfere, such as climate, age, hygiene, alimentary and cultural habits, socioeconomic strata and other habits that can result in greater contact with $T$. gondii ${ }^{33,59}$.

Regarding the prevalence of IgM antibodies, MITSUKA-BREGANÓ $(2009)^{41}$ and LOPES et al. $(2009)^{38}$ found a lower prevalence in pregnant women in Londrina, Paraná, which was $0.5 \%$ and $1.2 \%$, respectively. Similar results were found in pregnant women such as $2.2 \%$ in Santo Ângelo and $2.6 \%^{49}$ in Porto Alegre, both from the Rio Grande do Sul State.

The pregnant women resident in rural areas presented a prevalence of $75.68 \%$ (28/37) and a greater chance of infection by $T$. gondii (OR $=2.70$ ) when compared to the others from the urban areas (Table 2). SPALDING et al. $(2005)^{55}$ analyzed pregnant women in 29 cities in the region of Alto Uruguai, Rio Grande do Sul, and also detected a greater prevalence in the rural region, which was $78 \%$ compared to $71.3 \%$ in the urban region. MANDAI et al. $(2007)^{39}$ in the city of Londrina, Paraná reported a prevalence of $68.9 \%$ in the rural region and $55.7 \%$ in the urban region. LIU et al. (2009) ${ }^{37}$ also observed a greater chance of infection by $T$. gondii in pregnant women in rural areas in the northeast of China.

Regarding age group, the pregnant women aged from 36 to 45 presented a greater chance of infection by $T$. gondii $(\mathrm{OR}=2.40)$. This data lines up with studies carried out by LOPES et al. $(2009)^{38}$ in the city of Londrina, Paraná, where they observed that the prevalence of specific IgG antibodies increased with ages between 31 to 48 . In a study performed in Sergipe State with 9,500 pregnant women, a greater prevalence was found of anti-T. gondii antibodies proportionally to the age ${ }^{1}$. LEÃO et al. $(2004)^{34}$ analyzed pregnant woman from two maternities in Cuiabá, Mato Grosso do Sul State, and found a significant association between age and seropositivity. CADEMARTORI et al. $(2008)^{12}$ assessed 425 pregnant women attended in Basic Health Units in Pelotas, Rio Grande do Sul, and reported that as the age group increased, the seroprevalence also increased. SPALDING et al. $(2005)^{55}$ analyzed 2,126 pregnant women from 29 cities in Rio Grande do Sul State, who were attended by the Brazilian Public Health Service, and observed that the prevalence of infection increases in older age groups. DETANICO \& BASSO (2006) ${ }^{19}$, in the city of Caxias do Sul, Rio Grande do Sul, also reported a significant association between prevalence and the age of women studied $(p<0.001)$ with greater frequency in the ones between 37 to 49 years old $(51.7 \%)$. HUNG et al. $(2007)^{29}$ observed in the Democratic Republic of São Tomé and Príncipe that the $\operatorname{IgG}$ prevalence increased significantly $(85.7 \%)$ in pregnant women over 35 years old. This association can be explained by longer exposure time to the infective agent and reinforces the importance of routine serological screening in pregnant women.

Pregnant women with monthly family income less than one minimum wage (less than 380/415 BRL) and with a low educational level ( $\leq$ eight years of study) also showed greater chances of infection by $T$. gondii. Similar results were reported according to studies by AVELINO et al. $(2004)^{6}$ in pregnant women in Goiânia, Goiás State, and LOPES et al. $(2009)^{38}$ and MITSUKA-BREGANÓ $(2009)^{41}$ both in the city of Londrina, Paraná State. VARELLA et al. $(2003)^{59}$ in Porto Alegre, Rio Grande do Sul, noticed that maternal school education, especially of more than nine years of study, presented a clear protecting effect for anti-T. gondii seropositivity $(p \leq 0.001)$ and LIU et al. $(2009)^{37}$ in China noticed that pregnant women who did not attend school were more likely to be infected by $T$. gondii than those who did. These results show the importance of social, economic and educational investments as preventive methods against the diseases.

Another variable associated to infection by $T$. gondii was the number of pregnancies. Women who had been pregnant more than once presented a greater chance of infection by $T$. gondii $(p=0.0116)$. This result was similar to that observed by MITSUKA-BREGANÓ (2009) ${ }^{41}$ in Londrina, Paraná, and BIRGISDÓTTIR et al. (2006) ${ }^{10}$ in Sweden. AVELINO et al. $(2004)^{6}$, in Goiânia, Goiás, carried out a cohort study with women at fertile age and observed that the women previously pregnant were 1.7 times more likely of acquiring the infection than those who had never been pregnant before. It can be explained by the capacity of the mother's immune response and the gestational period in which the woman is, and the virulence of the parasite strain ${ }^{20}$. The maternal-fetal transmission and the severity of sequelae are related to gestational age when maternal infection occurs ${ }^{24}$. When the seroconversion occurs before 15 weeks of gestation, the rate of transmission to the fetus can be less than 5\%, nevertheless, the illness severity in newborns is higher. However, if the infection occurs late in pregnancy, near term, infection rates can reach $80 \%$, though the clinical manifestations are less severe ${ }^{50}$. Relationships between genotype and human disease certainly exist, but are still difficult to assess due to the role of host immune status and genetic background on the control of infection, and of other parasitic factors such as the infecting dose or parasite stage ${ }^{17}$. The severity of infection can be related with the parasite genotype, which describes three ancestral lineages of $T$. gondii and other recombinant and atypical strains ${ }^{48,53}$, and can be also related with the genetic susceptibility of the host (immune response, frequency of alleles of Major Histocompatibility Complex $)^{28}$. SOUZA (2009) ${ }^{54}$ genotyped 76 samples of amniotic fluid from pregnant women living in São Paulo State with serologic screening showing seroconversion and found $71.1 \%$ with the genotype II. As the genotypes I and III are considered, respectively, with high and intermediate pathogenicity, which often lead to miscarriages and premature births, could be underrepresented in studies that analyze pregnancies that reach the second and third quarterly periods, just like the case of the pregnant women included in this work ${ }^{54}$.

The drinking water which does not originate from the public water supply system implied a greater chance of infection by T. gondii ( $p=$ 0.0011). A similar result was reported by GALISTEU et al. $(2007)^{27}$, in 


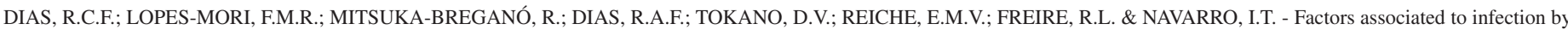
Toxoplasma gondii in pregnant women attended in Basic Health Units in the city of Rolândia, Paraná, Brazil. Rev. Inst. Med. Trop. Sao Paulo, 53(4): 185-91, 2011.

the city of São José do Rio Preto, São Paulo. In 1995, a major outbreak occurred in Canada with 100 individuals infected with toxoplasmosis due to consumption of untreated water contaminated by felid oocytes ${ }^{4,11}$. The largest world outbreak occurred in 2001 in Santa Isabel do Ivaí, Paraná, Brazil, where the municipal water reservoir was contaminated by oocytes from feces of young cats that lived in the location. 426 presented acute $T$. gondii infection and seven cases occurred in pregnant women. One had a spontaneous miscarriage and six had infected children, one of them with a serious congenital anomaly that resulted in death ${ }^{2}$. At present there are no specific regulations or approved methods to control T. gondii oocysts if present in public water supplies, and research in this area has been limited ${ }^{35,36}$.

The habit of handling soil or sand should also be considered in $T$. gondii infection. SPALDING et al. (2005) $)^{55}$ assessed pregnant women in the region of Alto Uruguai, Rio Grande do Sul, and verified that contact with the soil was the most important factor analyzed in the study. NASH et al. $(2005)^{45}$, in a study with pregnant women in Kent in the United Kingdom, did not find an association between infection and gardening but observed lower prevalence in the group that used gloves when handling the soil. It occurs due to the contamination of the soil by felid oocytes deposition in the feces of infected felines, that under ideal moisture and temperature conditions and in a favorable shady location can remain infected for 12 to 24 months $^{22}$. On the other hand, BARBOSA et al. $(2009)^{8}$ assessed pregnant women in Natal, Rio Grande do Norte, northeast of Brazil, and did not find an association between toxoplasmosis and gardening probably because of the climate of the region, which is dry and hot throughout the year.

The habit of handling raw meat, even at the limit of statistical significance $(p=0.0524)$, also offers the chance of infection by $T$. gondii. Studies have shown the importance of this factor, such as CADEMARTORI et al. (2008) $)^{12}$ who carried out a study with pregnant women in Pelotas, Rio Grande do Sul, and found high positive rates among those who handled raw meat. KAPPERUD et al. (1996) $)^{33}$ carried out a case-control study in Norway and related the low frequency in washing kitchen knives after preparing raw meat and before preparing another food to the risk of infection by $T$. gondii during pregnancy.

In the present study, the consumption of raw or poorly cooked meat was not associated with infection by $T$. gondii, in spite of it being known as an important means of transmission. Similarly, PORTO et al. $(2008)^{47}$ in Recife, Pernambuco State, and ERTUG et al. $(2005)^{25}$ in Turkey did not find an association between seropositivity to $T$. gondii and raw meat ingestion.

Contact with cats was also not associated to the chance of infection by $T$. gondii as reported in the studies by NASH et al. $(2005)^{45}$, PORTO et al. $(2008)^{47}$ and CADEMARTORI et al. $(2008)^{12}$. In contrast, LOPES et al. $(2009)^{38}$ and AVELINO et al. $(2004)^{6}$ obtained an association to the presence of cats. In relation to living with cats, the possibility of parasite transmission by the act of touching is minimal or nonexistent. The risk of infection might exist when there is contact with the feces of cats that are eliminating oocytes after the primary infection, and the feces of these animals could remain in the environment for at least 24 hours so that the oocytes sporulate and become infectant ${ }^{22}$.

The results observed in the present study led to the conclusion that seroepidemiological screening for toxoplasmosis in pregnant women should be adopted as routine and accompanied with orientations and counseling in the doctor's appointments so that educational practices and preventive measures can be adopted to prevent food contamination and thus prevent infection during pregnancy.

The IgG anti-T. gondii antibodies prevalence in the city of Rolândia was $55 \%$ and the factors associated to infection were residence in the rural area, pregnant women between 35 and 40 years of age, low educational level, monthly family income less than one minimum wage, more than one pregnancy, drinking water which does not originate from the public water supply system and the habit of handling soil or sand. Most of the factors associated to infection for $T$. gondii were relative to the social and demographic aspects that highlights the importance and need for investment in education and clean water supply for the population. It means that guidance on primary prevention measures and quarterly serological monitoring of the pregnant women in the risk group (seronegative) are important measures to prevent congenital toxoplasmosis.

The studies and evaluations conducted during the deployment of "Surveillance Program of Toxoplasmosis Acquired in Pregnancy and Congenital" in the city of Rolândia, Paraná were fundamental and strategical to order the actions, in the training of the health professionals, in establishing the routine for diagnosis and monitoring during pregnancy and in the toxoplasmosis notification.

\section{RESUMO}

\section{Fatores associados à infecção por Toxoplasma gondii em gestantes atendidas nas Unidades Básicas de Saúde do Município de Rolândia, Paraná, Brasil}

O objetivo deste trabalho foi determinar a prevalência de anticorpos IgG e IgM anti-Toxoplasma gondii e os fatores associados à infecção em gestantes atendidas nas Unidades Básicas de Saúde de Rolândia, Paraná, Brasil. A amostra foi dividida em dois grupos: grupo I (320 gestantes, analisadas entre julho de 2007 e fevereiro de 2008) e grupo II (287 gestantes, analisadas de março a outubro de 2008). No grupo I, foram encontrados 53,1\% de gestantes IgG reagente e IgM não reagente, $1,9 \%$ de $\operatorname{IgG}$ e IgM reagentes, $0,3 \%$ de IgG não reagente e IgM reagente e $44,7 \%$ de IgG e IgM não reagentes. No grupo II foram $55,1 \%$ de IgG reagente e $\operatorname{IgM}$ não reagente e $44,9 \%$ de $\operatorname{IgG}$ e $\operatorname{IgM}$ não reagentes. As variáveis associadas à infecção foram: residência em área rural, gestantes entre 35-40 anos de idade, baixa escolaridade, baixa renda familiar, mais de uma gravidez, consumo de água não proveniente do sistema de abastecimento público de água e hábito de manipular terra ou areia. As orientações sobre medidas de prevenção primária e o acompanhamento sorológico trimestral das gestantes no grupo de risco são medidas importantes para prevenir a toxoplasmose congênita.

\section{ACKNOWLEDGMENTS}

We thank the Municipal Health Secretariat of Rolândia, Paraná, Brazil and the University Hospital of Londrina State University. This study was supported by Conselho Nacional de Desenvolvimento Científico e Tecnológico (CNPq) and Fundação Araucária - Secretaria de Estado da Ciência, Tecnologia e Ensino Superior do Estado do Paraná. 
DIAS, R.C.F.; LOPES-MORI, F.M.R.; MITSUKA-BREGANÓ, R.; DIAS, R.A.F.; TOKANO, D.V.; REICHE, E.M.V.; FREIRE, R.L. \& NAVARRO, I.T. - Factors associated to infection by Toxoplasma gondii in pregnant women attended in Basic Health Units in the city of Rolândia, Paraná, Brazil. Rev. Inst. Med. Trop. Sao Paulo, 53(4): 185-91, 2011.

\section{REFERENCES}

1. Alves JAB, Oliveira LAR, Oliveira MFB, Araújo RM, Santos RCS, Abud ACF, et al. Prevalência de anticorpos anti-Toxoplasma gondii em mulheres grávidas. Rev Enferm UERJ. 2009;17:107-10.

2. Almeida MJ, Oliveira LHH, Freire RL, Navarro IT. Aspectos sócio-políticos da epidemia de toxoplasmose em Santa Isabel do Ivaí (PR). Ciênc Saúde Colet. 2011;16(Suppl 1):1363-73.

3. Antoniou M, Tzouvali H, Sifakis S, Galanakis E, Georgopoulou E, Liakou V, et al. Incidence of toxoplasmosis in 5532 pregnant women in Crete, Greece: management of 185 cases at risk. Eur J Obstet Gynecol Reprod Biol. 2004;117:138-43.

4. Aramini JJ, Stephen C, Dubey JP, Engelstoft C, Schwantje H, Ribble CS. Potential contamination of drinking water with Toxoplasma gondii oocysts. Epidemiol Infect. 1999;122:305-15.

5. Areal KR, Miranda AE. Soroprevalência de toxoplasmose em gestantes atendidas na rede básica de saúde de Vitória, ES. NewsLab. 2008;87:122-9.

6. Avelino MM, Campos Júnior D, Parada JB, Castro AM. Risk factors for Toxoplasma gondii infection in women of childbearing age. Braz J Infect Dis. 2004;8:164-74.

7. Baccarin FS, Oliveira TB. Prevalência de toxoplasmose em pacientes atendidos no laboratório Osvaldo Cruz em Santo Ângelo - RS. NewsLab. 2007;80:78-88.

8. Barbosa IR, Holanda CMCX, de Andrade-Neto VF. Toxoplasmosis screening and risk factors amongst pregnant females in Natal, northeastern Brazil. Trans R Soc Trop Med Hyg. 2009;103:377-82.

9. Batet CM, Guardià Llobet C, Juncosa Morros T, Viñas Domenech L, Sierra Soler M, Sanfelin Sala I, et al. Toxoplasmosis y embarazo. Estudio multicéntrico realizado en 16.362 gestantes de Barcelona. Med Clin (Barc). 2004;123:12-6.

10. Birgisdóttir A, Asbjörnsdottir H, Cook E, Gislason D, Jansson C, Olafsson I, et al. Seroprevalence of Toxoplasma gondii in Sweden, Estonia and Iceland. Scand J Infect Dis. 2006;38:625-31.

11. Bowie WR, King AS, Werker DH, Isaac-Renton JL, Bell A, Eng SB, et al. Outbreak of toxoplasmosis associated with municipal drinking water. Lancet. 1997;350:173-7.

12. Cademartori BG, Farias NAR, Brod CS. Soroprevalência e fatores de risco à infecção por Toxoplasma gondii em gestantes de Pelotas, Sul do Brasil. Rev Panam Infectol. 2008; $10: 30-5$.

13. Camargo ME. Improved technique of indirect immunofluorescence for serological diagnosis of toxoplasmosis. Rev Inst Med Trop Sao Paulo. 1964;6:117-8.

14. Camargo ME, Ferreira AW, Rocca A, Belem ZR. Um teste prático para sorologia da toxoplasmose, o teste de hemaglutinação. Estudo comparativo com os testes de imunofluorescência e imunoenzimático de captura de IgM. Rev Bras Patol Clin. 1986;22:196-201

15. Castilho-Pelloso MP, Falavigna DLM, Araújo SM, Falavigna-Guilherme AL. Monitoramento de gestantes com toxoplasmose em serviços públicos de saúde. Rev Soc Bras Med Trop. 2005;38:532-3.

16. Daffos F, Forestier F, Capella-Pavlovsky M, Thulliez P, Aufrant C, Valenti D, et al. Prenatal management of 746 pregnancies at risk for congenital toxoplasmosis. N Engl J Med. 1988;318:271-5.

17. Dardé ML. Toxoplasma gondii, “new” genotypes and virulence. Parasite. 2008;15:366-71.

18. Daunter B. Immunology of pregnancy: towards a unifying hypothesis. Eur J Obstet Gynecol Reprod Biol. 1992;43:81-95.

19. Detanico L, Basso RMC. Toxoplasmose: perfil sorológico de mulheres em idade fértil e gestantes. Rev Bras Anal Clin. 2006;38:15-18.
20. Desmonts G, Couvreur J. Congenital toxoplasmosis: a prospective study of 378 pregnancies. N Engl J Med. 1974;290:1110-6.

21. Dubey JP. Toxoplasmosis, sarcocystosis, isosporosis and cyclosporosis. In: Palmer SR, Soulsby EJL, Simpson DJH. Oxford: Oxford University Press; 1998.

22. Dubey JP. Sources of Toxoplasma gondii infection in pregnancy. Until rates of congenital toxoplasmosis fall, control measures are essential. BMJ. 2000;321:127-8.

23. Dubey JP, Lindsay DS, Speer CA. Structures of Toxoplasma gondii tachyzoites, bradyzoites, and sporozoites and biology and development of tissue cysts. Clin Microbiol Rev. 1998;11:267-99.

24. Dunn D, Wallon M, Peyron F, Petersen E, Peckhan C, Gilbert R. Mother-to-child transmission of toxoplasmosis: risk estimates for clinical counseling. Lancet. 1999;353:1829-33.

25. Ertug S, Okyay P, Turkmen M, Yuksel H. Seroprevalence and risk factors for Toxoplasma infection among pregnant women in Aydin province, Turkey. BMC Public Health. 2005;5:66.

26. Foulon W, Naessens A, Derde MP. Evaluation of the possibilities for preventing congenita toxoplasmosis. Am J Perinatol. 1994;11:57-62.

27. Galisteu KJ, Mattos CB, Lélis AGL, Oliveira MP, Spejorim LCJF, Jordão P, et al Prevalência e fatores de risco associados à toxoplasmose em grávidas e suas crianças no Noroeste Paulista, Brasil. Rev Panam Infectol. 2007;9:24-9.

28. Habegger de Sorrentino A, López R, Motta P, Marinic K, Sorrentino A, Iliovich E, et al. HLA Class II involvement in HIV-associated toxoplasmic encephalitis development. Clin Immunol. 2005;115:133-7.

29. Hung CC, Fan CK, Su KE, Sung FC, Chiou HY, Gil V, et al. Serological screening and toxoplasmosis exposure factors among pregnant women in the Democratic Republic of Sao Tome and Principe. Trans R Soc Trop Med Hyg. 2007;101:134-9.

30. Jacobs L. The interrrelation of toxoplasmosis in swine, cattle, dogs, and man. Public Health Rep. 1957;72:872-82.

31. Jenum PA, Stray-Pedersen B, Gundersen AG. Improved diagnosis of primary Toxoplasma gondii infection in early pregnancy by determination of antitoxoplasma immunoglobulin G avidity. J Clin Microbiol. 1997;35:1972-7.

32. Jenum PA, Stray-Pedersen B, Melby KK, Kapperud G, Whitelaw A, Eskild A, et al. Incidence of Toxoplasma gondii infection in 35,940 pregnant women in Norway and pregnancy outcome for infected women. J Clin Microbiol. 1998;36:2900-6.

33. Kapperud G, Jenum PA, Stray-Pedersen B, Melby KK, Eskild A, Eng J. Risk factors for Toxoplasma gondii infection in pregnancy: results of a prospective case-control study in Norway. Am J Epidem. 1996;144:405-12.

34. Leão PRD, Meirelles Filho J, Medeiros SF. Toxoplasmose: soroprevalência em puérperas atendidas pelo Sistema Único de Saúde. Rev Bras Ginecol Obstet. 2004;26:627-32.

35. Lindsay DS, Blagburn BL, Dubey JP. Survival of nonsporulated Toxoplasma gondii oocysts under refrigerator conditions. Vet Parasitol. 2002;103:9-13.

36. Lindsay DS, Collins MV, Mitchell SM, Cole RA, Flick GJ, Wetch CN, et al. Sporulation and survival of Toxoplasma gondii oocysts in seawater. J Eukaryot Microbiol. 2003;50(Suppl):687-8.

37. Liu Q, Wei F, Gao S, Jiang L, Lian H, Yuan B, et al. Toxoplasma gondii infection in pregnant women in China. Trans R Soc Trop Med Hyg. 2009;103:162-6.

38. Lopes FMR, Mitsuka-Breganó R, Gonçalves DD, Freire RL, Karigyo CJT, Wedy GF, et al. Factors associated with seropositivity for anti-Toxoplasma gondii antibodies in pregnant women of Londrina, Paraná, Brazil. Mem Inst Oswaldo Cruz. 2009;104:37882. 


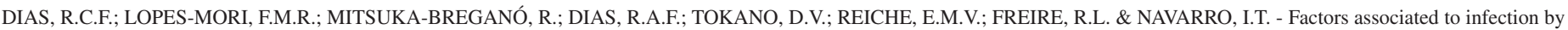
Toxoplasma gondii in pregnant women attended in Basic Health Units in the city of Rolândia, Paraná, Brazil. Rev. Inst. Med. Trop. Sao Paulo, 53(4): $185-91,2011$.

39. Mandai ON, Lopes FMR, Breganó RM. Prevalência de anticorpos IgG e IgM antiToxoplasma gondii em gestantes atendidas nas Unidades Básicas de Saúde do município de Londrina Paraná, no período de 2003 e 2004. Rev Bras Anal Clin. 2007;39:247-9.

40. Margonato FB, Silva AMR, Soares DA, Amaral DA, Petris AJ. Toxoplasmose na gestação: diagnóstico, tratamento e importância de protocolo clínico. Rev Bras Saude Mater Infant. 2007;7:381-6.

41. Mitsuka-Breganó R. Programa de vigilância em saúde da toxoplasmose gestacional e congênita: elaboração, implantação e avaliação no município de Londrina, Paraná. \{tese\}. Paraná: Universidade Estadual de Londrina; 2009.

42. Mitsuka-Breganó R, Lopes-Mori FMR, Navarro IT, organizadores. Toxoplasmose adquirida na gestação e congênita: vigilância em saúde, diagnóstico, tratamento e condutas. Londrina: EDUEL; 2010.

43. Montenegro CAB, Rezende-Filho J. Infecção congenital: I. Toxoplasmose. Femina 2000;28:495-7.

44. Montoya JG, Remington JS. Toxoplasma gondii. In: Mandell GL, Bennett JE, Dolin R, editors. Mandell, Douglas, and Bennett's principles and practice of infectious diseases. $5^{\text {th }}$ ed. Philadelphia: Churchil Livingstone; 2000. p. 2858-88.

45. Nash JQ, Chissel S, Jones J, Warburton F, Verlander NQ. Risk factors for toxoplasmosis in pregnant women in Kent, United Kingdom. Epidemiol Infect. 2005;133:475-83.

46. Nicolle C, Manceaux L. Sur un protozoaire nouveau de Gondi, Toxoplasma. Arch Inst Pasteur. 1909;2:97-103.

47. Porto AM, Amorim MM, Coelho IC, Santos LC. Perfil sorológico para toxoplasmose em gestantes atendidas em Maternidade. Rev Assoc Med Bras. 2008;54:242-8.

48. Reikvam A, Lorentzen-Styr AM. Virulence of different strains of Toxoplasma gondii and host response in mice. Nature. 1976;261:508-9.

49. Reis MM, Tessaro MM, D’Azevedo PA. Perfil sorológico para toxoplasmose em gestantes de um hospital público de Porto Alegre. Rev Bras Ginecol Obstet. 2006;28:158-64.

50. Remington JS, McLeod R, Desmonts G. Toxoplasmosis. In: Remington JS, Klein JO, editors. Infectious diseases of the fetus \& newborn infant. $4^{\text {th }}$ ed. Philadelphia: W.B. Saunders; 1995. p.140-267.
51. Rey LC, Ramalho ILC. Seroprevalence of toxoplasmosis in Fortaleza, Ceará, Brazil. Rev Inst Med Trop Sao Paulo. 1999;41:171-4.

52. Rolândia, Prefeitura. História de Rolândia. Available from: < http://www.rolandia.pr.gov. br/index.php?option=com_content\&view=article\&id=199\&Itemid=75. Accessed: 12 July, 2010.

53. Sibley LD. Toxoplasma gondii: perfecting an intracellular life style. Traffic. 2003;4:581-6.

54. Souza MVB. Tipagem molecular de Toxoplasma gondii: análise de líquidos amnióticos de gestações com diagnóstico de toxoplasmose congênita. [dissertação]. São Paulo: Universidade de São Paulo, Faculdade de Medicina; 2009.

55. Spalding SM, Amendoeira MRR, Klein CH, Ribeiro LC. Serological screening and toxoplasmosis exposure factors among pregnant women in South of Brazil. Rev Soc Bras Med Trop. 2005;38:173-7.

56. Spalding SM, Amendoeira MRR, Ribeiro LC, Silveira C, Garcia AP, Camillo-Coura L. Estudo prospectivo de gestantes e seus bebês com risco de transmissão de toxoplasmose congênita em município do Rio Grande do Sul. Rev Soc Bras Med Trop. 2003;36:483-91.

57. Tenter AM, Heckeroth AR, Weiss LM. Toxoplasma gondii: from animals to humans. Int J Parasitol. 2000;30:1217-58.

58. Uchôa CMA, Duarte R, Laurentino-Silva V, Alexandre GMC, Ferreira HG, Amendoeira MRR. Padronização de ensaio imunoenzimático para pesquisa de anticorpos das classes IgM e IgG anti-Toxoplasma gondii e comparação com a técnica de imunofluorescência indireta. Rev Soc Bras Med Trop. 1999;32:661-9.

59. Varella IS, Wagner MB, Darela AC, Nunes LM, Müller RW. Prevalência de soropositividade para toxoplasmose em gestantes. J Pediatr. 2003;79:69-74

60. Wilson M, Remington JS, Clavet C, Varney G, Press C, Ware D. Evaluation of six commercial kits for detection of human immunoglobulin M antibodies to Toxoplasma gondii. The FDA toxoplasmosis Ad Hoc Working Group. J Clin Microbiol 1997;35:3112-5.

Received: 22 February 2011

Accepted: 9 June 2011 